\title{
Disentangling the Impact of Civil Association Membership on Political Participation: Evidence from Swedish Panel Data
}

\author{
Linuz Aggeborn ${ }^{1}$ (D), Nazita Lajevardi ${ }^{2}$ and Pär Nyman ${ }^{3 *}$ (D) \\ ${ }^{1}$ Department of Government, Uppsala University, Uppsala Center for Fiscal Studies and Uppsala Center for Labor Studies, \\ Sweden, ${ }^{2}$ Department of Political Science, Michigan State University, USA and ${ }^{3}$ Department of Government, Uppsala \\ University \\ ${ }^{\star}$ Corresponding author. E-mail: par.nyman@statsvet.uu.se
}

(Received 28 November 2018; revised 1 October 2019; accepted 28 November 2019; first published online 18 June 2020)

\begin{abstract}
What is the effect of membership in civil associations on political participation? Membership has been linked to providing social capital and personal networks, which in turn help citizens more easily navigate politics. Yet this link is empirically complex, since politically interested individuals self-select into networks and associations. This research note addresses the impact of membership on different forms of political participation using a panel survey from Sweden that distinguishes between passive and active membership in various types of associations. The baseline results reaffirm a strong association between membership and political participation. The survey's panel dimension is exploited to reveal that earlier scholarship has likely overstated the robustness of membership's participatory effects. Rather, the remaining impact of association membership in the panel specification is mainly driven by types of associations for which the highest degree of selection behaviour is expected.
\end{abstract}

Keywords: political participation; civil associations; social capital; Sweden

Social capital is a central resource that increases trust (Fukuyama 1995; Ostrom and Ahn 2008; Putnam 2000) and connects individuals, different groups and societies (Verba and Nie 1987). Putnam $(2000,19)$ describes social capital as 'connections among individuals - social networks and the norms of reciprocity and trustworthiness that arise from them'. Social capital manifests as trust and civic attitudes, which in turn help citizens cooperate (Hooghe and Stolle 2003). When individuals are members of the same organization, they also take part in the same social network and may thus work together to reach mutual goals, which may in turn increase their political participation (Paxton 2002; Stolle and Rochon 1998; Wollebaek and Selle 2002).

Importantly for Putnam's theory, the formation of social capital and the acquisition of civic skills comes from active participation in organizations, where friends and acquaintances are part of the same social network. Scholarship has since concluded that social capital can also be acquired through passive membership (Teorell 2003; Wollebaek and Selle 2003) and through membership in different kinds of organizations (Teorell 2003). Understanding how membership in civil organizations increases political participation - and disentangling these effects - is crucial, given that studies from many different subfields frequently account for it in their kitchen sink models (for example, Cook, Page and Moskowitz 2014; Fleischmann, Martinovic and Böhm 2016; Grasso et al. 2019).

(C) The Author(s), 2020. This is an Open Access article, distributed under the terms of the Creative Commons Attribution licence (http://creativecommons.org/licenses/by/4.0/), which permits unrestricted re-use, distribution, and reproduction in any medium, provided the original work is properly cited. 
We return to this classic discussion in this research note. Our empirical strategy allows us to distinguish between passive and active membership in different kinds of civil society organizations. We expect active membership in such organizations to encourage political participation for several reasons. When individuals actively participate in these associations, they are likely to become friends. By meeting, they further educate one another, and learn in practice about the democratic process. These interactions may increase individuals' willingness to participate politically or even run for office (Lundin, Nordström-Skans and Zetterberg 2016; Hooghe, Stolle and Stouthuysen 2004).

Passive membership might also increase political participation because individuals gain cues that decrease the cost of participation (La Due Lake and Huckfeldt 1998; Teorell 2003). Passive membership might ensure that individuals are at least asked to participate, and as a result overcome Verba, Schlozman and Brady's $(1995,15)$ worry that individuals do not take part in politics 'because they can't; because they don't want to; or because nobody asked'. In line with this argument, we might also expect the number of associations to which a person belongs to also matter for political participation.

Nevertheless, some emerging scholarship has noted that self-selection hinders both assessments of the effects of membership in an association as well as the ability to distinguish between active and passive membership (Newton 1997; Paxton and Ressler 2018; Stolle 2003; Stolle and Rochon 1998; Uslaner 1998). Most studies in this field have yet to fully account for self-selection into civil organizations in their empirical analyses. ${ }^{1}$ Recent scholarly work in political science has begun to challenge traditional taken-for-granted causal relationships that affect political participation, such as the positive correlation between education and political participation (for example, Kam and Palmer 2008; Kam and Palmer 2011), by arguing that self-selection might be driving these relationships. We extend this line of research and argue that the positive relationship between membership in civil society organizations and political participation is similarly plagued by self-selection.

As Stolle and Rochon (1998) and Stolle (2003) note, we cannot causally estimate the effects of membership without accounting for this selection because individuals choose to join civil organizations. Moreover, those who trust more and those who participate more in politics might be more easily drawn to membership in associations (Stolle 2003, 25). ${ }^{2}$ Because individuals choose membership in civil organizations, we cannot causally estimate the effects of membership without accounting for this selection. The self-selection problem is present for both passive and active membership, though to differing degrees.

We should be most worried about self-selection when it comes to active membership (Hooghe 2003, 97). Individuals who are inclined to participate in politics may also be more likely to become active members of organizations, simply because they enjoy meeting and discussing with other people or because they have the resources to do so. Passive membership in an organization, however, may be an attractive choice for many other practical reasons, such as receiving a discount, organizational support or insurance purposes that certain associations provide to their members. We might also expect membership in associations more closely connected to the political sphere (for example, environmental organizations) to be more likely due to selection based on prior political interest, whereas membership in other types of associations (such as sports organizations) is comparatively less linked to the political arena.

Our data's panel dimension allows us to better deal with the issue of selection behavior, which arguably has led previous research to exaggerate the effect that association membership has on political participation. While some scholarly work has used panel data to examine the

\footnotetext{
${ }^{1}$ Nonetheless, Stolle and Rochon (1998) do address self-selection to the best of their ability when examining the relationship between association membership and social trust in Sweden and Germany.

${ }^{2}$ This issue of endogeneity is also highlighted in Teorell $(2003,58)$, who discusses a follow-up survey, though could not include a panel dimension in his analysis.
} 
relationship between association membership and social trust (for example, Bekkers 2012; Van Ingen and Kalmijn 2010; Van Ingen and Bekkers 2015), ours is the first to use panel data to examine the readily accepted - though rarely tested - relationship between association membership and political participation. We also distinguish between active and passive membership, as well as between membership in different kinds of organizations.

\section{Data}

Our analysis centers on Sweden. Associations in Sweden are numerous; the average adult is associated with nine associations (Lundström and Wijkström 1997). ${ }^{3}$ However, political participation in Sweden is already high, which could mean that rates of membership in civil associations are due to self-selection.

To assess membership in civil society associations, we rely on Statistics Sweden's yearly Swedish Living Conditions Survey (ULF/SILC). The survey is administered through personal interviews, and a subset of respondents belong to a panel survey conducted every seven years. We focus our empirical analyses on this panel of individuals.

Our outcome variables capture different forms of political participation. First, we study voter turnout in European Parliament elections rather than Swedish national elections, because these have more variation in turnout. Secondly, we study other acts of political participation, such as contacting political officials and participating in demonstrations. ${ }^{4}$ We conduct a factor analysis for all dependent variables except for voter turnout. Our prior is that variation in the variables may be captured in one factor, which is confirmed in Figure A1. We thus have two main dependent variables in our main empirical analysis: voter turnout and the first factor score for these other measures. ${ }^{5}$

Our right-hand side variables come from questions on civil society associations in the ULF surveys. We include information on passive and active membership in an association. We also account for the type of association. In the main analysis, we include binary indicators for reported passive or active membership in any organization and a count variable for the number of passive and active memberships a respondent reports. We only focus on associations that were included twice in the survey so that we can run panel regressions. ${ }^{6}$

Our final dataset consists of a pooled panel dataset administered in three different waves: (1) 1992 and 1993, (2) 2000 and 2001 and (3) 2008 and 2009. For voter turnout, we only use the second and third waves, because Sweden did not elect representatives to the European Parliament before becoming an EU member in 1995.

The empirical analysis is conducted in two parts. First, we pool the data from all years together and estimate the associations between membership (separating passive and active membership) and our two outcome variables. Next, we conduct a panel data analysis. We estimate the two regression equations below.

$$
Y_{i}=\beta_{0}+\beta_{1} \text { Association }_{i}+\beta_{2} W_{i}+u_{i}
$$

\footnotetext{
${ }^{3}$ This is high in comparison to the average number of association membership worldwide. Schofer and Fourcade-Gourinchas (2001) summarize evidence from the World Values Survey and find Sweden, Iceland and the United States are at the top, while Japan, France and Italy are at the bottom.

${ }^{4}$ This includes contacting municipal civil servants, writing opinion pieces (local and national newspaper), signing petitions (local and national issues), demonstrating and protesting (local and national), and other local political activities.

${ }^{5}$ Outcome variables originate from the ULF survey, except voter turnout in the last election, which we developed from register data. The survey question asked whether an individual voted in the last election for the European Parliament (the 1999 election), whereas the register data record whether the individual actually voted in the 2009 election.

${ }^{6}$ The number of included associations differs between survey years, see Table A16. We do not include associations that are inherent acts of political participation, e.g., belonging to a political party.
} 


$$
Y_{i, t}=\beta_{0}+\beta_{1} \text { Association }_{i, t}+\beta_{2} W_{i, t}+f_{i}+\tau_{t}+e_{i, t}
$$

$$
t \in\{1,2\}
$$

$Y$ is voter turnout or the factor score for the other political participation measures, while $u i$ and $e_{i}$, ${ }_{t}$ are error terms. Association is an individual's reported membership in the survey, which is either a binary variable for any type of passive or active membership or a count variable for the number of passive or active memberships. $W$ is a vector of covariates including years of education, employment status, age, gender, immigration status, standardized income for each cohort and year, and whether the person's family receives social welfare. $f_{i}$ refers to individual fixed effects, and $\tau_{t}$ represents period fixed effects.

To assess the effects of membership in associations on political participation, it is helpful to think about the ideal randomized experiment. In such an experiment, we would randomize individuals into passive, active and no membership in different types of civil society organizations. This design would keep all other factors constant and would isolate the causal effect of interest. Given that we are unable to run such an experiment, we attempt to partially overcome some of these concerns in Equation 2.

By including fixed effects, we account for all characteristics that fluctuate between individuals but that remain constant over periods, and for characteristics that vary over time periods but are constant between individuals. In the present case, we only use the variation in political participation and civil association membership within the individual unit over the two time periods. We demonstrate the degree of between- and within-unit variation in our dependent and independent variables in Appendix Tables A2-A5.

We are careful to not argue that these estimated coefficients in Equation 2 amount to causal estimates, however. Such an analysis requires a more elaborate identification strategy with exogenous variation in membership. ${ }^{8}$ Notwithstanding these limitations, the estimates in Equation 2 are less plagued by self-selection concerns, and can provide empirical results that may nuance earlier empirical findings on the relationship between membership in organizations and political participation.

\section{Main results}

Table 1 presents the results from our first model (Equation 1), where we regress our measures of political participation on civil association membership and our set of socioeconomic control variables. ${ }^{9}$ We distinguish between passive and active membership where an individual cannot be an active member without also being a passive member. The estimated coefficients for active

\footnotetext{
${ }^{7}$ We choose not to control for variables like political interest in our analyses, because the causal direction between this variable and organizational membership would be unclear. We acknowledge, however, that there are arguments both in favor of and against controlling for such variables. On the one hand, not controlling for political interest may exaggerate the effect that membership has on participation, because both membership and participation may be caused by a high level of political interest. On the other hand, if membership has a causal effect on participation, and this effect is mediated by political interest, controlling for political interest could underestimate this effect. Gender and immigration status are not included in the panel regression since this variation is captured in the included fixed effects.

${ }^{8}$ One possible identification strategy would be to run an instrumental variable (IV) analysis (e.g., Angrist, Imbens and Rubin 1996; Heckman 1990). However, it is inherently difficult to implement such a strategy for the question at hand, since it would require two instruments because we study membership and active membership. These instruments also need to fulfil the exclusion restriction that the instruments cannot affect the outcome directly. For instance, instruments such as geographical closeness to civil associations or moving may also affect political participation, thus invalidating them.

${ }^{9}$ See Table A6 for the corresponding model without covariates.
} 
Table 1. Pooled data with covariates

\begin{tabular}{|c|c|c|c|c|}
\hline & $\begin{array}{c}1 \\
\text { Turnout EP }\end{array}$ & $\begin{array}{c}2 \\
\text { Turnout EP }\end{array}$ & $\begin{array}{c}3 \\
\text { PP factor score }\end{array}$ & $\begin{array}{c}4 \\
\text { PP factor score }\end{array}$ \\
\hline Member in any org. & $\begin{array}{l}0.072^{\star \star \star} \\
(0.012)\end{array}$ & & $\begin{array}{l}0.121^{\star \star \star} \\
(0.033)\end{array}$ & \\
\hline Active in any org. & $\begin{array}{l}0.033^{\star *} \\
(0.016)\end{array}$ & & $\begin{array}{l}0.260^{\star * *} \\
(0.025)\end{array}$ & \\
\hline Member in \# of org. & & $\begin{array}{l}0.044^{\star \star \star} \\
(0.007)\end{array}$ & & $\begin{array}{l}0.139^{\star \star \star} \\
(0.013)\end{array}$ \\
\hline Active in \# of org. & & $\begin{array}{r}0.016^{*} \\
(0.010)\end{array}$ & & $\begin{array}{l}0.136^{\star \star \star} \\
(0.021)\end{array}$ \\
\hline Constant & $\begin{array}{l}0.162^{\star \star \star} \\
(0.039)\end{array}$ & $\begin{array}{l}0.185^{\star \star \star} \\
(0.038)\end{array}$ & $\begin{array}{l}-1.554^{\star \star \star} \\
(0.082)\end{array}$ & $\begin{array}{l}-1.481^{\star \star \star} \\
(0.079)\end{array}$ \\
\hline Covariates? & Yes & Yes & Yes & Yes \\
\hline Time dimension data? & Pooled data & Pooled data & Pooled data & Pooled data \\
\hline Adjusted $\mathrm{R}^{2}$ & 0.050 & 0.054 & 0.088 & 0.110 \\
\hline Observations & 8,118 & 8,198 & 8,468 & 8,468 \\
\hline
\end{tabular}

Note: robust standard errors in parentheses. ${ }^{*} \mathrm{p}<0.1,{ }^{\star \star} \mathrm{p}<0.05,{ }^{\star \star \star} \mathrm{p}<0.01$

membership should thus be interpreted as the additional impact of active membership. ${ }^{10}$ With one exception, the estimated coefficients for our variables of interest are statistically significant at the 5 per cent level. The first column in Table 1 reveals that being a passive member of any organization is associated with a 7.2-percentage-point increase in the probability of voting in the European election. For someone who is also an active member of the organization, their voting propensity increases by an additional 3.3 percentage points. A similar pattern is found for other forms of participation. Being a passive member of an organization is associated with an increase in the factor score of political participation by 0.12 standard deviations. For active members, the factor score is estimated to increase by approximately $0.4(0.12+0.26)$ standard deviations.

The results from Table 1 confirm prior scholarship and reveal a positive relationship between membership and political participation, but the estimated coefficients are plagued by selfselection. Members of civil associations are likely very different from non-members, and it is unlikely that we have controlled away these differences and obtained estimates where all else is equal except for civil association membership.

We therefore turn to our panel analysis (Equation 2) next and present the results in Table 2. Using this empirical strategy, the estimated coefficients decrease substantially in magnitude, but remain positive despite rarely manifesting as statistically significant. Voter turnout data are displayed in the first column: being a passive member is no longer associated with a large increase in the probability of voting in European Parliament elections. The estimated coefficient for passive membership, which is no longer statistically significant, corresponds to a 1.3-percentage-point increase in the likelihood of voting for passive members of any civil association. Active membership in an organization continues to have a statistically significant impact on the factor score, but the estimated impact is smaller than in Table 1. For the factor score, we do still estimate one positive and statistically significant coefficient for the number of passive memberships, but the coefficient is again smaller in size.

These results demonstrate that the relationship between membership in civil associations and political participation is rather nuanced, and that the previously observed strong "effects" of civil association membership are likely due to a high degree of self-selection behavior. For robustness, we provide results from a propensity score matching analysis in Appendix Figures A2-A4 and

\footnotetext{
${ }^{10}$ We code all those who are not active members as 0 when we study active membership. This variable thus includes both those who are not members at all and those who are only passive members.
} 
Table 2. Panel data analysis

\begin{tabular}{|c|c|c|c|c|}
\hline & $\begin{array}{c}1 \\
\text { Turnout EP }\end{array}$ & $\begin{array}{c}2 \\
\text { Turnout EP }\end{array}$ & $\begin{array}{c}3 \\
\text { PP factor score }\end{array}$ & $\begin{array}{c}4 \\
\text { PP factor score }\end{array}$ \\
\hline Member in any org. & $\begin{array}{c}0.013 \\
(0.012)\end{array}$ & & $\begin{array}{c}0.054 \\
(0.041)\end{array}$ & \\
\hline Active in any org. & $\begin{array}{c}0.022 \\
(0.016)\end{array}$ & & $\begin{array}{l}0.071^{\star \star} \\
(0.028)\end{array}$ & \\
\hline Member in \# of org. & & $\begin{array}{c}0.005 \\
(0.007)\end{array}$ & & $\begin{array}{l}0.042^{\star \star \star} \\
(0.015)\end{array}$ \\
\hline Active in \# of org. & & $\begin{array}{c}0.016 \\
(0.010)\end{array}$ & & $\begin{array}{c}0.028 \\
(0.023)\end{array}$ \\
\hline Constant & $\begin{array}{c}6.927 \\
(12.979)\end{array}$ & $\begin{array}{c}6.542 \\
(12.878)\end{array}$ & $\begin{array}{l}61.950^{\star \star \star} \\
(1.807)\end{array}$ & $\begin{array}{l}62.283^{\star \star \star} \\
(1.592)\end{array}$ \\
\hline Covariates? & Yes & Yes & Yes & Yes \\
\hline Individual fixed effects? & Yes & Yes & Yes & Yes \\
\hline Time period fixed effects? & Yes & Yes & Yes & Yes \\
\hline Time dimension data? & Panel & Panel & Panel & Panel \\
\hline Adjusted $\mathrm{R}^{2}$ & 0.218 & 0.220 & 0.012 & 0.013 \\
\hline Observations & 8,118 & 8,198 & 8,468 & 8,468 \\
\hline
\end{tabular}

Note: clustered robust standard errors at the individual level in parentheses. ${ }^{\star} p<0.1,{ }^{\star \star} p<0.05,{ }^{\star \star \star} p<0.01$

Table A13. We have also run analyses for different age groups, presented in Tables A14-A15, as well as analyses where we use an additive index instead of the factor score as the dependent variable (Table A7) and analyze each participation indicator separately (Table A8).

\section{Distinguishing between different types of associations}

Given that the theoretical causal chain runs from membership to social capital and finally to political participation, it is likely that different associations yield various degrees of social capital, and thus have differential impacts on political participation. The degree of self-selection is also likely larger for some types of associations compared to others. The panel data analysis in the main results section rests on the premise that the difference in characteristics between individuals is captured by the inclusion of individual fixed effects, time fixed effects, and covariates where the identifying variation stems from within-subject variation between time periods 1 and 2 . However, it is unlikely that the estimated coefficients from the previous section are causal estimates, given that we have not accounted for all types of self-selection behavior in our analyses.

To take these analyses one step further, we introduce an approach of categorizing associations into two groups and run the panel data analysis for each organization separately. Our purpose here is to investigate whether the positive associations found in Table 2 are primarily driven by membership in organizations where we suspect a high degree of self-selection may exist. If so, the claim that membership in civil associations leads to higher political participation is further weakened. $^{11}$

We distinguish between high and low self-selection to address two different concerns. First, we worry about reverse causality, which is likely present for membership in organizations more closely connected to the political sphere. As previously discussed, a person who is participating in demonstrations may be more likely to join a political organization or protest group. We have therefore put peace organizations, environmental organizations and women's organizations in the high self-selection group. Secondly, some associations (for example, parental and pension

\footnotetext{
${ }^{11}$ Since we only have voter turnout data from 1995, we may not use the first survey wave for this outcome variable. Because questions concerning the explicit type of association differed somewhat between the survey waves, the types of organizations included here differ somewhat from the analysis for voter turnout and the factor score. See Table A16 for details.
} 
Table 3. Organizations grouped with different level of selection bias (high and low)

\begin{tabular}{|c|c|c|c|c|}
\hline & $\begin{array}{c}1 \\
\text { Turnout EP }\end{array}$ & $\begin{array}{c}2 \\
\text { Turnout EP }\end{array}$ & $\begin{array}{c}3 \\
\text { PP factor score }\end{array}$ & $\begin{array}{c}4 \\
\text { PP factor score }\end{array}$ \\
\hline Member in any high selection & $\begin{array}{l}0.057^{\star \star} \\
(0.025)\end{array}$ & & $\begin{array}{c}-0.136 \\
(0.098)\end{array}$ & \\
\hline Active in any high selection & $\begin{array}{c}0.042 \\
(0.032)\end{array}$ & & $\begin{array}{c}0.129 \\
(0.204)\end{array}$ & \\
\hline Member in any low selection & $\begin{array}{c}-0.023 \\
(0.025)\end{array}$ & & $\begin{array}{c}0.669 \\
(0.480)\end{array}$ & \\
\hline Active in any low selection & $\begin{array}{c}0.013 \\
(0.025)\end{array}$ & & $\begin{array}{c}-0.191 \\
(0.467)\end{array}$ & \\
\hline Member in \# of high selection & & $\begin{array}{l}0.031^{\star \star} \\
(0.014)\end{array}$ & & $\begin{array}{c}-0.026 \\
(0.036)\end{array}$ \\
\hline Active in \# of high selection & & $\begin{array}{c}0.033 \\
(0.024)\end{array}$ & & $\begin{array}{l}0.132^{* *} \\
(0.062)\end{array}$ \\
\hline Member in \# of low selection & & $\begin{array}{c}-0.005 \\
(0.009)\end{array}$ & & $\begin{array}{c}0.033 \\
(0.021)\end{array}$ \\
\hline Active in \# of low selection & & $\begin{array}{c}0.014 \\
(0.012)\end{array}$ & & $\begin{array}{l}0.056^{\star *} \\
(0.028)\end{array}$ \\
\hline Constant & $\begin{array}{c}9.350 \\
(14.780)\end{array}$ & $\begin{array}{c}7.514 \\
(12.654)\end{array}$ & $\begin{array}{l}69.204^{\star \star \star} \\
(4.635)\end{array}$ & $\begin{array}{l}65.336^{\star \star \star} \\
(1.854)\end{array}$ \\
\hline Covariates? & Yes & Yes & Yes & Yes \\
\hline Individual fixed effects? & Yes & Yes & Yes & Yes \\
\hline Time period fixed effects? & Yes & Yes & Yes & Yes \\
\hline Time dimension data? & Panel & Panel & Panel & Panel \\
\hline Adjusted $\mathrm{R}^{2}$ & 0.257 & 0.221 & 0.023 & 0.014 \\
\hline Observations & 5,070 & 8,198 & 3,445 & 8,468 \\
\hline
\end{tabular}

Note: clustered robust standard errors at the individual level in parentheses. ${ }^{*} p<0.1,{ }^{* *} p<0.05,{ }^{* * *} p<0.01$

associations) are only open to people who fall within a certain age range. For these associations, our fixed effects are not able to capture latent confounding factors that may be shaping their membership. Thus, we expect a higher degree of selection bias to still be present in the panel regression with membership in these organizations. The remaining associations (for example, sports, housing, culture associations (theatre and dance), and organizations for immigrants and persons with disabilities) are categorized into the low self-selection group.

The analysis is presented in Table 3, and estimates the same model as in Table 2 but with separate effects for associations where we expect high self-selection and for those where we expect smaller selection bias. Beginning with voter turnout, membership in low-self-selection associations (passive and active membership) has no positive impact on voter turnout. The point estimates are sometimes positive and sometimes negative, but always small in magnitude and statistically insignificant. For high-self-selection associations, we estimate consistently positive and sometimes statistically significant coefficients for both passive membership and active membership. Overall, these results suggest that the positive 'effect' of membership on voter turnout is mainly driven by high-self-selection associations, which could mean that the remaining impact is simply a result of self-selection due to political interest and not due to a causal effect of membership in civil society associations. For the factor score analysis, we estimate both negative and positive coefficients depending on the specification. We find two statistically significant results related to the number of associations a person belongs to. Here, we find a positive impact for both the high- and low-selection groups on the factor score. Nonetheless, these results should be interpreted with caution, given that the other estimates vary greatly.

For completeness, we have also run the entire analysis for all types of association separately (not grouped together). Appendix Tables A9-A12 present these results, which substantiate our main findings. 


\section{Discussion and conclusion}

Political scientists have long acknowledged the importance of social capital when explaining political participation. Notably, Putnam (2000) argued that trust between individuals is promoted through active participation in associations. Theoretically, this hypothesis is intuitive, given that trust is likely to form through face-to-face contact. Others have instead reasoned that quantity is more important than quality; the number of associations is more important for increased political participation (Teorell 2003).

As demonstrated in this research note, there are obstacles associated with both hypotheses. Individuals optimize based on what they derive utility from, meaning that an individual who has a high interest in politics also likely enjoys spending time in an association. More generally, a person who already possesses trust in others will likely join associations. When operationalizing social capital, researchers should take into account that both passive and active participation in associations are highly endogenous.

Our results question whether membership in civil associations actually has a causal effect on political participation. While they reaffirm a correlation between membership in associations and political participation, we find that this relationship is due to selection bias and not to a causal effect. We propose that survey research should continue to ask about membership in different types of associations and about the intensity of membership, though researchers should also remain wary about selection because association membership is not random. Future research implementing experimental designs (for example, like Dahl, Kotsadam and Rooth 2018), where individuals are randomized in their association membership, may help estimate the causal link, while also accounting for self-selection and unobserved heterogeneity.

Finally, our results have implications for the historical debate on civic associations, which saw Skocpol et al. (1999) and Skocpol, Ganz and Munson (2000) argue for an institutional approach in which a more complex relationship forms through vertical and horizontal ties in civic associations. By contrast, Putnam (2000) maintained that civic associations foster activism primarily through horizontal ties. While we do not come down on one side in this debate, our results indicate that self-selection would plague both the institutional and the horizontal approaches. Thus, in each of these theoretical frameworks, we suggest addressing self-selection.

Supplementary material. Data replication sets are available at: https://doi.org/10.7910/DVN/Z5COGF and online appendices are available at https://doi.org/10.1017/S0007123419000772.

For more information regarding data access for replication purposes, please see page 20 in the online appendix.

Acknowledgements. We are grateful to Karl-Oskar Lindgren, Sven Oskarsson, the editor Rob Johns and the anonymous reviewers for their constructive comments and suggestions, which helped to significantly improve the manuscript. We also thank seminar participants at the 2018 Michigan State University Political Economy of Voting workshop. This research was funded by the European Research Council (ERC), grant number 683214 CONPOL. This paper circulated earlier under the title "How membership in civil associations affects political participation: Evidence from Sweden".

\section{References}

Angrist JD, Imbens GW and Rubin DB (1996) Identification of causal effects using instrumental variables. Journal of the American Statistical Association 91(434), 444-455.

Aggeborn L, Lajevardi N and Nyman P (2019) "Replication Data for: Disentangling the impact of civil association membership on political participation”, https://doi.org/10.7910/DVN/Z5COGF, Harvard Dataverse, V1.

Bekkers R (2012) Trust and volunteering: selection or causation? Evidence from a 4 year panel study. Political Behavior 34(2), 225-247.

Cook FL, Page BI and Moskowitz RL (2014) Political engagement by wealthy Americans. Political Science Quarterly 129(3), 381-398.

Dahl G, Kotsadam A and Rooth D.-O. (2018) Does integration change gender attitudes?: the effect of randomly assigning women to traditionally male teams. Working paper No. 24351. Cambridge, MA: National Bureau of Economic Research.

Fleischmann F, Martinovic B and Böhm M (2016) Mobilising mosques?: The role of service attendance for political participation of Turkish and Moroccan minorities in the Netherlands. Ethnic and Racial Studies 39(5), 746-763.

Fukuyama F (1995) Trust: The Social Virtues and the Creation of Prosperity. New York: Free Press. 
Grasso MT et al. (2019) Socialization and generational political trajectories: an age, period and cohort analysis of political participation in Britain. Journal of Elections, Public Opinion and Parties 29(2), 199-221.

Heckman J (1990) Varieties of selection bias. American Economic Review 80(2), 313-318.

Hooghe M (2003) Voluntary associations and democratic attitudes. In Hooghe M and Stolle D (eds), Generating Social Capital, 89-111. New York: Palgrave Macmillan.

Hooghe M and Stolle D (2003) Introduction: generating social capital. In Hooghe M and Stolle D (eds), Generating Social Capital, 1-18. New York: Palgrave Macmillan.

Hooghe M, Stolle D and Stouthuysen P (2004) Head start in politics: the recruitment function of youth organizations of political parties in Belgium (Flanders). Party Politics 10(2), 193-212.

Kam CD and Palmer CL (2008) Reconsidering the effects of education on political participation. The Journal of Politics 70 (3), 612-631.

Kam CD and Palmer CL (2011) Rejoinder: reinvestigating the causal relationship between higher education and political participation. The Journal of Politics 73(3), 659-663.

La Due Lake R and Huckfeldt R (1998) Social capital, social networks, and political participation. Political Psychology 19(3), 567-584.

Lundin M, Nordström-Skans $\mathbf{O}$ and Zetterberg P (2016) Leadership experiences within civil organizations and candidacy in public elections: causal evidence from a quasi-experimental approach. Political Behavior 38(2), 433-454.

Lundström T and Wijkström F (1997) The Nonprofit Sector in Sweden. Manchester: Manchester University Press.

Newton K (1997) Social capital and democracy. American Behavioral Scientist 40(5), 575-586.

Ostrom E and Ahn T.-K. (2008) Social capital and collective action. In Castiglione D, Van Deth JW and Wolleb G (eds), The Handbook of Social Capital, 70-100. Oxford: Oxford University Press.

Paxton P (2002) Social capital and democracy: an interdependent relationship. American Sociological Review 67(2), $254-277$.

Paxton P and Ressler RW (2018) Trust and participation in associations. In Uslaner EM (ed.), The Oxford Handbook of Social and Political Trust, 149-172. Oxford: Oxford University Press.

Putnam RD (2000) Bowling alone: America's declining social capital. In Crothers L and Lockhart C (eds), Culture and Politics: A Reader, 223-234. New York: Palgrave Macmillan US.

Schofer E and Fourcade-Gourinchas M (2001) The structural contexts of civic engagement: voluntary association membership in comparative perspective. American Sociological Review 66(6), 806-828.

Skocpol T, Ganz M and Munson Z (2000) A nation of organizers: the institutional origins of civic voluntarism in the United States. American Political Science Review 94(3), 527-546.

Skocpol T, et al. (1999) How Americans became civic. In Skocpol T and Fiorina MP (eds), Civic Engagement in American Democracy, 27-80. Washington, DC: Brookings Institution Press.

Stolle D (2003) The sources of social capital. In Hooghe M and Stolle D (eds), Generating Social Capital, 19-42. New York: Palgrave Macmillan.

Stolle D and Rochon TR (1998) Are all associations alike?: member diversity, associational type, and the creation of social capital. American Behavioral Scientist 42(1), 47-65.

Teorell J (2003) Linking social capital to political participation: voluntary associations and networks of recruitment in Sweden. Scandinavian Political Studies 26(1), 49-66.

Uslaner EM (1998) Social capital, television, and the 'mean world': trust, optimism, and civic participation. Political Psychology 19(3), 441-467.

Van Ingen E and Kalmijn M (2010) Does voluntary association participation boost social resources? Social Science Quarterly 91(2), 493-510.

Van Ingen E and Bekkers R (2015) Generalized trust through civic engagement?: evidence from five national panel studies. Political Psychology 36(3), 277-294.

Verba S, Schlozman KL and Brady HE (1995) Voice and Equality: Civic voluntarism in American politics. Cambridge, MA: Harvard University Press.

Verba S and Nie NH (1987) Participation in America: Political democracy and social equality. Chicago, IL: University of Chicago Press.

Wollebaek D and Selle P (2002) Does participation in voluntary associations contribute to social capital? Nonprofit and Voluntary Sector Quarterly 31(1), 32-61.

Wollebaek D and Selle P (2003) The importance of passive membership for social capital formation. In Hooghe M and Stolle D (eds), Generating Social Capital, 67-88. New York: Palgrave Macmillan.

Cite this article: Aggeborn L, Lajevardi N, Nyman P (2021). Disentangling the Impact of Civil Association Membership on Political Participation: Evidence from Swedish Panel Data. British Journal of Political Science 51, 1773-1781. https://doi.org/ $10.1017 /$ S0007123419000772 